\title{
APLIKASI 3D PRINTER FUSED DEPOSITE MATERIAL (FDM) PADA PEMBUATAN POLA COR
}

\author{
Hamid Abdillah ${ }^{1, *}$, Ulikaryani ${ }^{2}$ \\ ${ }^{1,2}$ Teknologi Pengecoran Logam, Politeknik Manufaktur Ceper \\ Batur, Tegalrejo, Kec. Ceper, Kab. Klaten, 57465 \\ *E-mail: vici.hamid@gmail.com
}

\begin{abstract}
ABSTRAK
Industri Pengecoran Logam memiliki masalah klasik dalam menangani proses produksi dan penjaminan kualitas. Penelitian ini memberikan solusi untuk memecahkan masalah industri pengecoran logam dengan memperkenalkan dan menerapkan 3D printer dengan sistem fused deposit material. Teknologi ini digunakan untuk mengefektifkan proses produksi pola cor. Proses pembuatan pola cor biasanya mengambil $70 \%$ dari keseluruhan waktu produksi sebuah produk cor. Tujuan dari penelitian ini adalah mengkaji penerapan pembuatan pola cor dengan 3D printer dengan sistem fused deposit material. Metode penelitian yang dilakukan adalah (1) penggambaran 3D CAD pola cor, (2) konversi ke format STL, (3) 3D printer setup, (4) proses print, (5) analisis, (6) kesimpulan. Hasil yang diperoleh adalah 3D printer dengan sistem fused deposit material dapat digunakan untuk melakukan pembuatan pola cor. Dari analisis ketelitian pola cor dengan 3D printer memiliki selisih ukuran berkisar 0,2mm. Sedangkan untuk analisis kualitas geometri, hasil pola cor dari 3D printer dengan sistem fused deposit material memiliki bentuk yang baik tetapi kurang pada hasil permukaannya. Dengan demikian 3D printer dengan sistem fused deposit material layak digunakan untuk pembuatan pola cor karena memiliki ketelitian yang cenderung konsisten dan kemudahan dalam pembuatan pola cor. Hal ini membuka peluang untuk pengembangan lanjutan untuk 3D printer pada sektor industri pengecoran logam.
\end{abstract}

Kata kunci: Pola Cor; FDM; 3D Printer; Pengecoran Logam.

\begin{abstract}
Metal Casting Industry has a classic problem in handling the production process and quality assurance. This research aims to provide solutions to solve the problems of the metal casting industry by introducing and applying 3D printers with a fused deposit material system. This technology is used to streamline the production process of cast patterns. The process of making a casting pattern usually takes $70 \%$ of the total production time of a cast product. The purpose of this study is to examine the application of making cast patterns with a $3 D$ printer with a fused deposit material system. The research methods carried out are (1) create of $3 D C A D$ cast patterns, (2) conversion to STL format, (3) 3D printer setup, (4) printing process, (5) analysis, (6) conclusions. The results obtained are a $3 D$ printer with a fused deposit material system that can be used to make cast patterns. From the analysis of the accuracy of the cast pattern with the 3D printer has a difference in size ranging from $0.2 \mathrm{~mm}$. As for the analysis of the quality of the geometry, the results of the cast pattern of the $3 D$ printer with the fused deposit material system have a good shape but lack results on the surface. Thus a $3 D$ printer with a fused deposit material system is suitable for making cast patterns because it has a consistent tendency and ease in making cast patterns. This opens up opportunities for continued development of $3 D$ printers in the metal casting industry sector.
\end{abstract}

Keywords: Casting Pattern; FDM; 3D Printer; Metal Casting. 


\section{PENDAHULUAN}

Pengecoran logam merupakan salah satu metode dalam memproduksi benda dengan mencairkan logam kemudian menuangkan dalam cetakan. Kelebihan dari sector pengecoran adalah mampu membuat benda yang sederhana dan rumit dengan sekali proses. Oleh karena itu, metode pengecoran sangat sering digunakan untuk prototipe pengembangan produk dan produksi masal. Hampir 90\% dari seluruh barang yang produksi dalam sektor manufaktur dilakukan melalui proses pengecoran logam [1].

Berdasarkan 45th Census of World Casting Production [2] menyebutkan bahwa sektor pengecoran logam memiliki kontribusi yang besar dalam pertumbuhan ekonomi beberapa negara besar. Pertumbuhan produksi industri pengecoran dunia meningkat 13.7\% dari tahun 2009 ke 2010. Akan tetapi, pada 50th Census of World Casting production [3], pertumbuhan industri pengecoran logam dunia cenderung stagnan dalam 3 tahuin terakhir. Pertumbuhan industri pengecoran logam pada tahun 2015 hanya $0.4 \%$ dan pada tahun 2014 hanya $2.37 \%$.

Globalisasi, inovasi dan kebutuhan untuk terus berkembang serta meningkatkan efektifitas produksi menjadi tantangan tersendiri bagi sector pengecoran logam di era industri 4.0. Industri pengecoran memiliki peranan yang kuat dalam bidang manufaktur dan pertumbuhan ekonomi, akan tetapi harus juga didukung dengan penguatan teknologi untuk menghadapi kompetitor lain [4]. Sektor pengecoran logam juga harus mampu memenuhi ekpektasi dari para pelanggan dalam penjaminan kualitas, pemangkasan waktu produksi dan harga yang kompetitif [5]

Inovasi mutlak untuk dilakukan dalam menghadapi era industri 4.0. Persaingan di era industri 4.0 saat ini tidak ditentukan oleh besar kecilnya suatu peusahaan akan tetapi ditentukan oleh ide-ide inovasi baru yang memberikan nilai lebih dan menyelesaikan masalah bagi konsumen. Inovasi bisnis yang bisa dilakukan pada model bisnis, produksi dan pelayanan [6]. Dalam industri pengecoran logam, inovasi yang dapat dilakukan adalah inovasi dalam hal proses produksi. Dengan adanya inovasi proses produksi, perusahaan dapat memotong dan mengefisienkan proses produksi dengen mneggunakan sentihan teknologi-teknologi produksi baru yang berkembang di era industri 4.0.

Sektor pengecoran logam sebagai salah satu industri manufaktur yang banyak digunakan untuk memproduksi komponenkomponen mesin tentunya harus menyusun strategi untuk dapat menghadapi tantangan perkembangan dan revolusi zaman. beberapa strategi yang dapat ditempuh sektor pengecoran logam untuk menghadapi tantangan industri 4.0 di abad 21 adalah: (1) melakukan pengembangan teknologi dan penambahan penggunaan teknologi lain untuk menunjang produktifitas, (2) manajemen pekerjaan, khususnya pekerjaan yang kompleks, (3) menguatkan hubungan kerjasama, (4) mereduksi biaya produksi, (5) mengadakan Research \& Development (R\&D) yang berkelanjutan [7].

Penggunaan teknologi untuk menunjang produktifitas, manajemen pekerjaan kompleks dan mereduksi biaya produksi merupakan permasalahan yang utama dalam sektor pengecoran logam. Hal ini disebabkan oleh proses produksi yang panjang. Proses pengecoran logam pada umumnya terdiri dari : (1) pembuatan pola coran dan cetakan, (2) peleburan, (3) penuangan dan (4) finising benda coran. Pola coran merupakan merupakan replika dari benda yang akan di cor. Pola coran menjadi acuan dalam proses pembuatan cetakan cor. Waktu pengerjaan sebuah pengecoran logam didominasi oleh persiapan pembuatan pola dan cetakan. Waktu yang dibutuhkan untuk pembuatan pola cor memakan hampir 70\% dari waktu produksi [8]. Dalam proses pembuatannya, pola cor
masih didominasi oleh pengerjaan
konvensional dengan bahan baku kayu atau
resin. Waktu pengerjaan pembuatan pola ini
tergantung dari tingkat kerumitan benda yang
akan di cor. Semakin rumit bentuk dan ukuran
benda yang akan dibuat menjadi faktor penentu
durasi pembuatan pola cor. Oleh karena itu
pembuatan dan kualitas pola coran menjadi
kunci penting dalam proses pengecoran. Hal
ini dikarenakan pembuatan pola merupakan
langkah pertama dalam proses pengecoran dan 
pola dengan kualitas permukaan dan dimensi yang akurat akan meminimalkan cacat las [9].

Pembuatan pola apabila ditinjau dari kualitas geometri dan dimensi pola cor ditentukan dari keterampilan pekerja dan proses finising pembuatan pola. Keterampilan pekerja menjadi penentu kualitas geometri dan dimensi dari pola cor yang dibuat sehingga semakin kompleks pola yang dibuat akan semakin tinggi pula keterampilan pekerja yang dibutuhkan. Sedangkan untuk memperoleh cetakan dan hasil cor yang baik, kualitas permukaan dari pola menjadi faktor yang berpengaruh cukup besar, sehingga dalam pembuatan pola pasti dilakukan proses finising dan pelapisan untuk memperoleh pola dengan kualitas permukaan yang baik dan memiliki durabilitas yang cukup lama. Oleh karena itu proses dan kebutuhan produksi pola tersebut berimplikasi pada waktu dan biaya produksi pola.

\begin{abstract}
Berdasarkan penjabaran tersebut, gambaran peluang peningkatan efektivitas melalui rekayasa pola pembuatan pola yang lebih efektif. Salah satu teknologi yang digadang dalam revolusi industri adalah 3D printer. 3D printer merupakan perangkat yang memproduksi produk dengan cara menambahkan bahan (additive manufaktur) yang sesuai dengan input program berupa gambar 3D CAD yang dikonversi ke format stereolithography (STL). 3D printer terdiri dari beberapa jenis sistem kerja seperti Fused Deposit Material (FDM), Selective Laser Sintering (SLS) dsb. Sistem FDM merupakan sistem 3D printer yang mudah dan banyak dikembangkan pada saat ini. Penelitian ini bertujuan untuk melakukan revolusi proses pembuatan polacor dengan menggunakan 3D printer sistem FDM
\end{abstract}

\section{METODE PENELITIAN}

Penelitian mengenai aplikasi 3D printer FDM pada pembuatan polacor dilakukan dengan urutan langkah-langkah sebagai berikut:

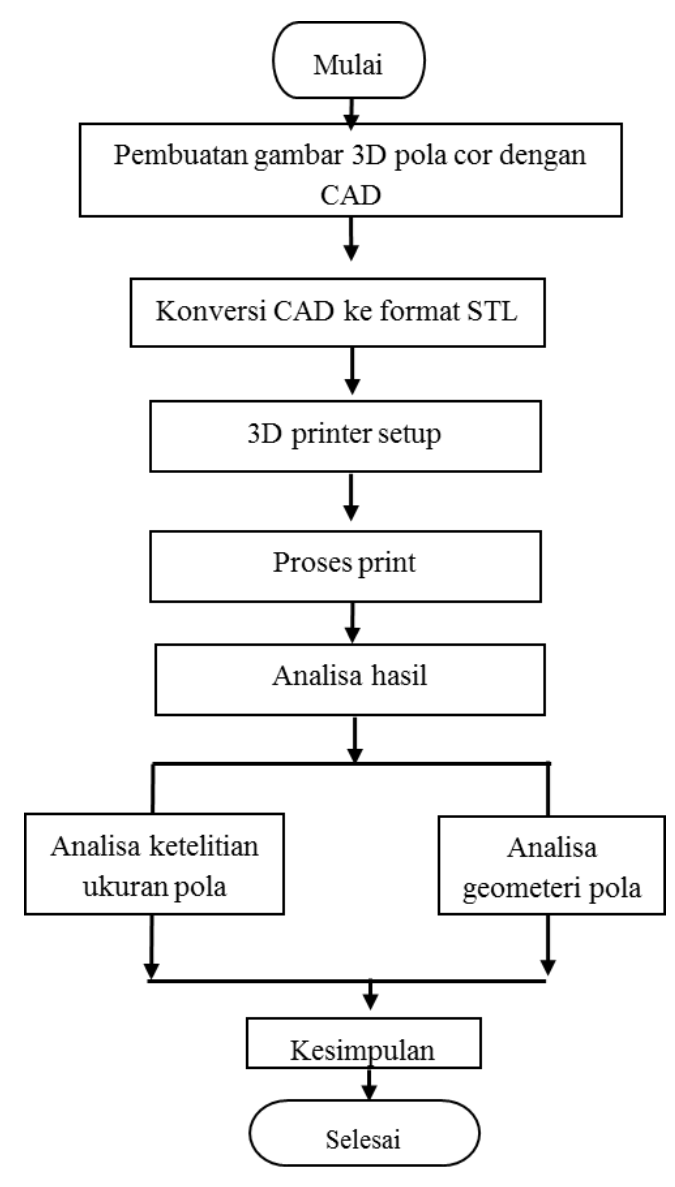

Gambar 1. Diagram Alir Penelitian

\subsection{Material}

Alat yang digunakan dalam penelitian ini adalah 3D printer dengan sistem FDM dengan kapasitas produksi 150x150x150 mm. Bahan baku filament 3D printer yang digunakan adalah Poly lactic acid (PLA) dengan diameter $1.75 \mathrm{~mm}$. PLA merupakan material biodegradable thermoplastic aliphatic polyester dengan struktur molekul $\left(\mathrm{C}_{3} \mathrm{H}_{4} \mathrm{O}_{2}\right)_{\mathrm{n}}$. PLA terbuat dari sumber terbarukan seperti tepung jagung, tapioka atau tebu.

\subsection{Analisis Data}

Analisis yang dilakukan dari pola cor yang dihasilkan dengan 3D printer adalah analisis ketelitian ukuran produk dan kualitas geometeri. Analisis keterlitian ukuran produk dilakukan dengan melakukan pengukuran langsung hasil 3D printer dengan menggunakan jangka sorong digital. Bagianbagian yang dukur disajukan dalam dalam gambar 2. Setiap bagian yang diukur dibagi menjadi 3 titik pengukuran. Sedangkan analisis 
kualitas geometeri lakukan secara visual untuk mengkaji bentuk dan kehalusan permukaan pola cor yang dihasilkan dengan 3D printer.
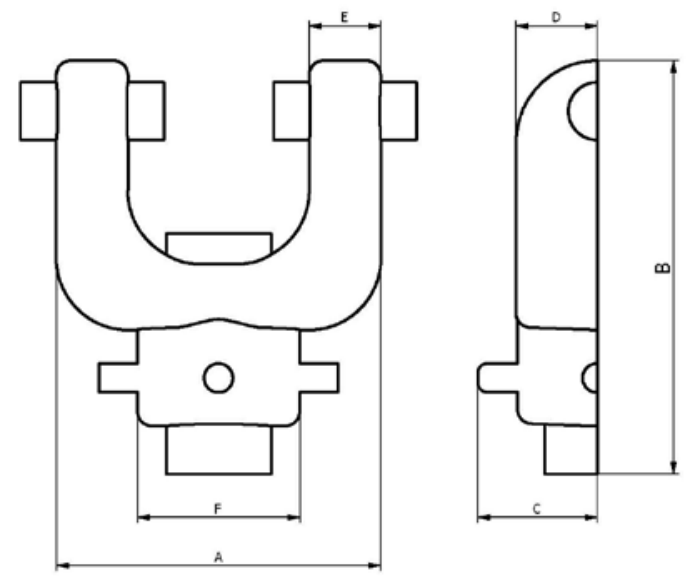

Gambar 2. Bagian-bagian dari pola cor yang akan diukur

\section{HASIL DAN PEMBAHASAN}

\subsection{Pembuatan Gambar 3D CAD}

Sesuai dengan metode yang digunkan, awal penelitian ini dilakukan dengan melakukan reverse engineering produk yang akan dibuat. Proses ini menggunakan software CAD Autodesk Inventor Profesional 2018 Education Version. Produk yang dipilih untuk dibuat pola cornya adalah fork. Fork merupakan produk dengan tingkat kerumitan yang rendah. Fork adalah komponen yang biasa digunakan untuk sambungan transmisi yang tidak consentris (satu sumbu). Fork dipilih sebagai pola dengan tingkat kerumitan rendah dikarenakan bentuk geometrinya yang mudah dan tidak memliki banyak sudut.

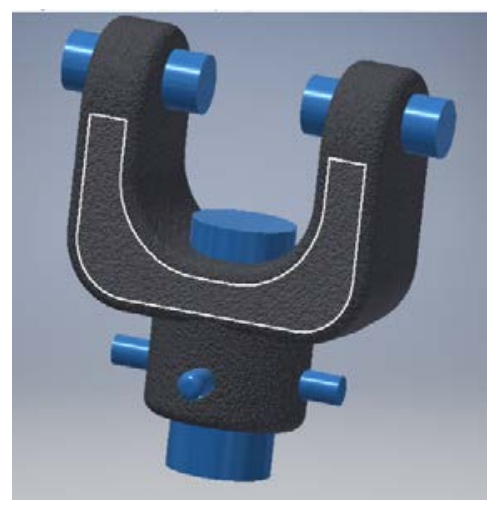

Gambar 3. 3D CAD Pola Cor
Fork yang digunakan memiliki ukuran mayor 90x90x20mm. Keterangan gambar 3, yang berwarna hitam merupakan permukaan benda yang akan di cor dan yang berwarna biru adalah core pin (dudukan inti).

\subsection{Konversi ke format STL}

Hasil penggambaran 3D CAD fork dikonversi menjadi file STL. Hal ini dilakukan karena software slicer dari 3D printer hanya memiliki kompakbilitas dengan dengan format STL. Proses konversi ini dapat dilakukan secara langsung dari software Autodesk Inventor 2018 dengan menggunakan feature save as yang kemudin diubah format file menjadi STL.

Sebagai catatan, proses konversi ke format dilakukan dengan melakukan pengaturan output file STL minimal satuan default file dan resolusi file. Hal ini dilakukan untuk meminimalisir kekeliruan dimensi produk saat file STL di proses pada software slicer dari 3D printer. Sehingga output dari produk 3D printer memiliki akurasi yang lebih baik.

Pengaturan pada kualitas file STL yang dibuat juga berpengaruh pada hasil bentuk geometeri produk yang dikerjakan dengan 3D printer. Semakin baik resolusi file STL yang digunakan akan berpengaruh pada ketelitian GKode pergerakan 3D printer.

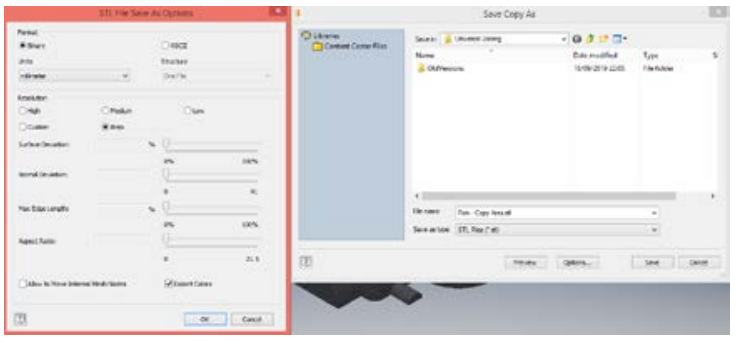

Gambar 4. Pengaturan konversi ke format SLT

\subsection{D Printer Setup}

Pengaturan 3D printer dilakukan dengan menggunakan software XYZware dari Da vinci Minimaker. XYZware dipilih karena merupakan software bawaan dari 3D printer 
yang digunakan. Percobaan pembuatan pola fork menggunakan parameter print infill density $20 \%$, layer height $0.2 \mathrm{~mm}$, dan medium speed. Estimasi waktu pembuatan diperkirakan memakan waktu 2 jam 9 menit.

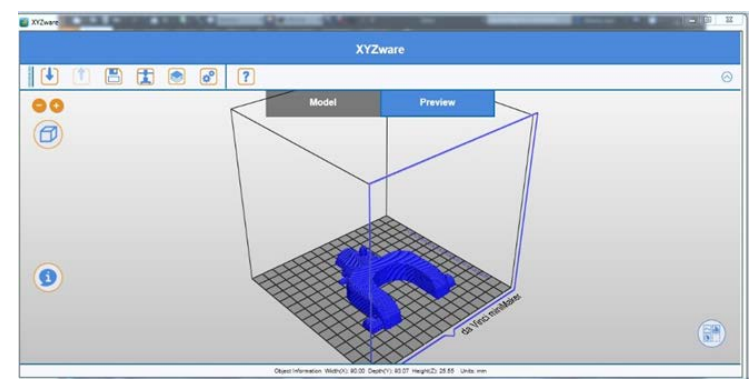

Gambar 5. Setup dan Slicing file STL

\subsection{Proses Print}

Proses print dilakukan setelah pengaturan paramter print dan proses slicing objek STL selesai dilakukan. Proses print polacor disajikan pada gambar 6 . Waktu print yang dibutuhkan lebih lama dari waktu estimasi yang digambarkan pada simulasi software. Simulasi software menunjukan waktu estimasi pengerjaan adalah 2 jam 9 menit, sedangkan waktu real pembuatan adalah 2 jam 28 menit. Dengan demikian prediksi dan kenyataan dari waktu pembuatan memiliki gap sebesar 17 menit.

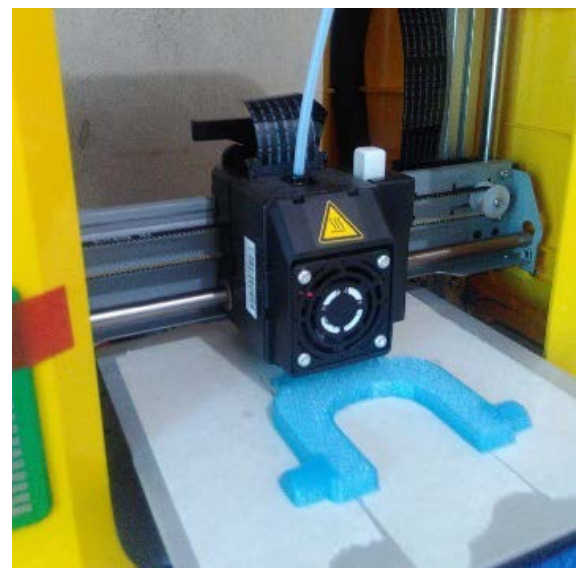

Gambar 6. Proses Print Pola Cor

\subsection{Pembahasan}

Hasil dari pola cor fork yang dibuat dengan 3D printer sistem FDM dapat dilihat pada gambar 7. Apabila ditinjau dari sisi bentuk geometri, pola cor yang dihasilkan sudah memiliki bentuk yang baik atau sama dengan gambar 3D CAD yang dibuat. Akan tetapi pola cor ini memiliki kelemahan pada kualitas permukaan yang dihasilkan. Kualitas permukaan pola cor yang dihasilkan kurang rata dan bergerigi.

Profil permukaan yang bergerigi ini disebabkan oleh sistem kinerja 3D printer FDM. 3D printer sistem FDM menggunakan filament berdiamater $1.75 \mathrm{~mm}$ sebagai bahan baku. Filament ini kemudian diolah menjadi benang tipis dengan diameter $0,2 \mathrm{~mm}$ (sesuai pengaturan layer height) oleh extruder. Benang tipis ini kemudian disusun lapis demi lapis sampai menjadi bentuk yang diinginkan. Ole karena itu, permukaan bergerigi pada pola cor merupakan efek dari proses ektruksi dari filament 3D printer.

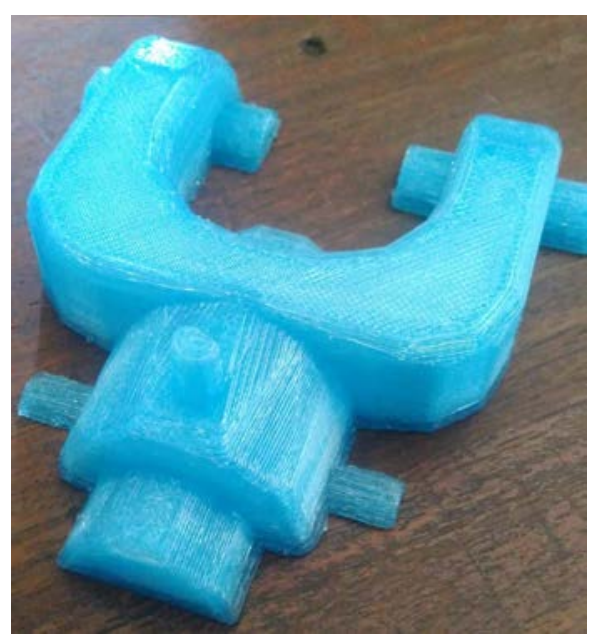

Gambar 7. Hasil 3D Print Pola Cor

Analisis ketelitian produk pola cor yang dihasilkan oleh 3D printer dengan sistem FDM dapat dilihar pada tabel 1. Dari rerata hasil pengukuran pola cor fork, diperoleh penyimbangan ukuran berkisar $0.2 \mathrm{~mm}$ pada masing-masing bidang yang diukur. Pada bidang $\mathrm{A}, \mathrm{B}, \mathrm{E}$ dan $\mathrm{F}$ penyimpangan yang terjadi adalah penyimpangan positif atau adanya penambahan ukuran. Sedangkan pada bidang $C$ dan $D$ penyimpangan yang terjadi adalah penyimpangan negatif atau ada pengurangan ukuran.

Secara umum terlihat besaran penyimpangan adalah $0.2 \mathrm{~mm}$ atau sama dengan nilai paramater layer height yang digunakan. Hal ini bisa membuktikan bahwa 
besarnya toleransi pada pola cor yang dibuat dengan 3D printer sistem FDM dipengaruhi oleh besarnya parameter layer height yang digunakan. Sehingga untuk mengatur kualitas ketelitian dari pola cor yang dibuat dapat dilakuakan dengan menentukan ukuran paramter layer height yang digunakan.

Tabel 1. Hasil pengukuran dimensi* pola cor

\begin{tabular}{ccccccc}
\hline & $\mathrm{A}$ & $\mathrm{B}$ & $\mathrm{C}$ & $\mathrm{D}$ & $\mathrm{E}$ & $\mathrm{F}$ \\
\hline P1 & 68,15 & 86,11 & 24,63 & 16,67 & 15,09 & 34,17 \\
P2 & 68,24 & 86,20 & 24,81 & 16,76 & 15,19 & 34,26 \\
P3 & 68,24 & 86,20 & 24,72 & 16,76 & 15,19 & 34,17 \\
Mean & 68,21 & 86,17 & 24,72 & 16,73 & 15,15 & 34,20 \\
CAD & 68 & 86 & 25 & 17 & 15 & 34 \\
Gap & 0,21 & 0,17 & $-0,28$ & $-0,27$ & 0,15 & 0,20
\end{tabular}

*) satuan dimensi : mm

Fenomena lain yang muncul adalah adanya perbedaan jenis toleransi yang terjadi pada bidang $\mathrm{A}, \mathrm{B}, \mathrm{E}, \mathrm{F}$ dengan bidang $\mathrm{C}$ dan D. Apabila ditinjau dari posisi bidang tersebut, bidang A, B, E, F terletak pada posisi horisontal dan bidang C, D terletak pada posisi vertikal. Dari posisi tersebut terlihat bahwa bidang C, D segaris dengan arah gravitasi. Hal ini memungkinkan adanya pergeseran dan teknanan kebawah pada bidang tersebut sehingga menyebabkan dimensi yang terbentuk mengalami pengurangan.

\section{KESIMPULAN}

Kesimpulan yang dapat diperoleh pada penelitian ini adalah penggunaan 3D printer dengan sistem FDM memungkinkan dan layak untuk pembuatan pola cor. Hal ini dikarenakan produk pola yang dihasilkan memiliki bentuk geometri dan ketelitian yang baik. Dengan demikian aplikasi 3D printer dengan sistem FDM dapat digunakan dalam sektor pengecoran logam dan masih memiliki peluang pengembangan untuk meningkatkan kualitas dari produk yang dihasilkan.

\section{DAFTAR PUSTAKA}

[1] A. Lupulescu, S. Henry, K. Marken et al. 2015, "Science of Casting and Solidification:
ASM Handbook Contributions-Honoring Professor Doru Michael Stefanescu," Advances in the Science and Engineering of Casting Solidification, pp. 3-8: Springer.

[2] 45th Census of World Casting Production, vol. 12, 2011.

[3] 50th Census of World Casting Production, vol. 16, 2016.

[4] S. Dalquist, and T. Gutowski, 2004 "Life cycle analysis of conventional manufaktur techniques: sand casting." pp. 631-641.

[5] B. Ravi, 1999. "Computer-aided casting design-past, present and future," Korea, vol. 1, no. 1.48, pp. 777.

[6] M. Rüßmann, M. Lorenz, P. Gerbert et al., 2015. "Industri 4.0: The future of productivity and growth in manufaktur industries," Boston Consulting Group, vol. 9.

[7] M. Chang, 2007. "Foundry future: challenges in the 21st century." pp. 18-23.

[8] Pal, D., \& Ravi, B. (2007). Rapid tooling route selection and evaluation for sand and investment casting. Virtual and Physical Prototyping, 2(4), 197-207.

[9] Lampman, S. (2009). Casting Design and Performance. Ohio : ASM International. 